Online: http://journal.uny.ac.id/index.php/jppfa

\title{
KEBIJAKAN PENDIDIKAN BAHASA ASING DI INDONESIA DALAM PERSPEKTIF MASYARAKAT GLOBAL
}

Banun Havifah Cahyo Khosiyono

Universitas Negeri Yogyakarta

J1. Colombo No. 1, Depok, Sleman 55281, Yogyakarta, Indonesia

Email: banuna.havifah90@gmail.com

\begin{abstract}
Abstrak
Tujuan dalam artikel ini adalah untuk mengetahui kebijakan pendidikan bahasa Asing di Indonesia dalam perspektif masyarakat global. Artikel ini pemaparkan kebijakan pendidikan bahasa Asing di Indonesia dalam menghadapi era globalisasi. Kebijakan pendidikan bahasa Asing di Indonesia mengalami perubahan dari Indonesia merdeka hingga saat ini. Perubahan ini disebabkan karena perubahan kurikulum yang mengalami karena penyempurnaan kurikulum-kurikulum sebelumnya. Sehingga, kebijakan pendidikan Bahasa Asing disesuaikan dengan tujuan kurikulumkurikulum dari masa setelah kemerdekaan hingga saat ini.
\end{abstract}

Kata kunci: kebijakan, pendidikan bahasa Asing, masyarakat global

\section{THE POLICY OF FOREIGN LANGUAGE EDUCATION IN INDONESIA WITHIN GLOBAL COMMUNITY PERSPECTIVE}

\begin{abstract}
The aims of this article is to know the policy of Foreign language education in Indonesia in perspective of global society. This article to explain the policy of Foreign language education in Indonesia in facing globalization era. The policy of foreign language education in Indonesia is changing from Indonesia get independent until now. This changing because curriculum become different and the causing is finishing the curriculum before. Therefore, the policy of foreign language education must appropriate with the aims of curricula from In Indonesia get independent until now. Keywords: policy, foreign language education, global society
\end{abstract}




\section{PENDAHULUAN}

Globalisasi merupakan sebuah simbol dunia yang banyak digunakan dalam sebuah kenyataan global yang menekankan kehidupan dalam sebuah konsep lingkungan baru, salah satu karakteristiknya adalah teknologi informasi (Kheng \& Baldauf, 2011, p. 952). Manusia hidup di dunia saat ini dibentuk secara terus menerus dalam perubahan pengalaman global seperti pada ruang lingkup politik, ekonomi, sosial, maupun pengaruh lingkungan. Yang kemudian globalisasi terdiri dari banyak dimensi proses sosial dalam intensitas sosial di seluruh dunia yang menciptakan hubungan lebih dalam antara manusia di seluruh dunia (Steger, 2003). Pentingnya hubungan ini di dalam konteks perubahan global mempengaruhi arah bahasabahasa dalam penyebaran dan penggunaan di tempat-tempat yang lebih besar yang menekankan pada situasi komunikasi yang efektif dalam lingkup individu, organisasi, institusi, dan pemerintah pada tingkat melintasi seluruh dunia.

Oleh karena itu, dalam menghadapi era globalisasi yang ditandai oleh kemajuan pesat dalam teknologi informasi dan komunikasi telah menjadikan penguasaan bahasa asing (Inggris, Perancis, Mandarin, Jepang, Jerman, dan bahasa asing lainnya) sebagai syarat utama untuk mengembangkan diri sehingga mampu bersaing di tengah masyarakat global. Perkembangan ini ditunjukkan dengan banyaknya negara yang dulu memposisikan bahasa Inggris sebagai bahasa asing kini mulai memposisikan bahasa Inggris sebagai bahasa kedua. Sebagaimana contohnya di Singapura, bahasa Inggris digunakan sebagai bahasa kedua di negaranya. Berbeda dengan Indonesia yang masih memposisikan bahasa Inggris sebagai bahasa Asing.

Disamping itu, masa depan bahasabahasa di dunia seperti bahasa Indonesia, Inggris, dan bahasa Asing lainnya sangat berkaitan erat dengan kekuatan ekonomi di Negaranegara. Sebagaimana seperti bahasa Inggris berasal dan Inggris yang menyebar ke negaranegara commonwealth. Demikian pula bahasa Perancis yang sampai sekarang masih dipakai sebagai bahasa pengantar di beberapa negara di Timur Tengah. Bahasa Mandarin yang sekarang diminati dan dipelajari oleh banyak orang karena kebangkitan ekonominya. Selain itu pula bahasa Jepang dan bahasa Jerman yang banyak diminati karena sudah menjadi bahasa teknologi dan dikenal sebagai negara yang maju dalam teknologinya.

Dalam menghadapi permasalahanpermasalahan tersebut, maka pendidikan bahasa Asing dibutuhkan agar peserta didik dapat berpartisipasi dan beradaptasi dalam menghadapi era globalisasi di dunia. Sehingga, dalam menghadapi era globalisasi setiap negara di dunia mempunyai kebijakan-kebijakan pendidikan bahasa Asing di negera-negaranya masing-masing terutama dalam pendidikan formal. Dalam hal ini, maka makalah ini lebih memfokuskan kebijakan pendidikan bahasa Asing di Indonesia.

Berdasarkan paparan tersebut, maka permasalahan dalam makalah ini adalah "Bagaimana kebijakan pendidikan bahasa Asing di Indonesia dalam perspektif masyarakat global?" Tujuan dalam makalah ini adalah untuk mengetahui kebijakan pendidikan bahasa Asing di Indonesia dalam perspektif masyarakat global.

\section{Masyarakat Global dan Tuntutannya}

Lahirnya kesepakatan AFTA, APEC, dan European Common Market merupakan perwujudan perubahan pola hubungan internasional yang kemudian lahirlah paradigma baru yang dikenal dengan istilah globalisasi (Huda, 2011, p. 59). Globalisasi adalah sebuah kata yang digunakan dalam melambangkan sebuah kenyataan gobal yang menekan kehidupan didalam sebuah konsep lingkungan yang baru, salah satunya dikarakteristikkan dengan teknologi informasi (Kheng \& Baldauf, 2011, p. 952). Globalisasi dapat dipahami sebagai kekuatan dalam melakukan tekanan dalam standard dan menciptakan tuntutan dalam seluruh masyarakat (Jarvis, 2007).

Gejala penduniaan (globalisasi) hubungan ekonomi international didukung oleh revolusi teknologi informasi yang pada tahap berikutnya merambah ke bidang-bidang lain seperti sosial, budaya, dan politik. Kemajuan teknologi informasi sperti faksimile, parabola, cetak jarak jauh, telepon seluler, CD-ROM, dan internet, serta kemajuan dibidang transportasi, telah memfasilitasi interaksi global secara amat signifikan. Batas-batas fisik antar negara kurang berfungsi lagi, dan bangsabangsa di dunia telah berubah menjadi suatu masyarakat global. 
Dalam perubahan ke dalam masyarakat global, terdapat dua implikasi pokok terhadap perubahan dan perkembangan masyarakat global (Huda, 2011, p. 60). Pertama, telah terjadi persaingan antarbangsa yang semakin ketat. Dan kedua, peningkatan interaksi global memerlukan bahasa sebagai alat berkomunikasi. Dalam hal ini, penguasaan bahasa asing menjadi lebih penting. Penguasaan bahasa asing merupakan persyaratan penting bagi keberhasilan individu dalam menjawab tantangan zaman. Pendidikan bahasa Asing dapat dijadikan salah satu sarana utama dalam rangka meningkatkan kualitas diri, masyarakat, dan bangsa. Bahasa yang dimiliki oleh bangsa akan unggul dalam bidang ekonomi, politik, dan iptek memiliki peluang menjadi wahana komunikasi global. Bahasa-bahasa global seperti bahasa Perancis, bahasa Jerman, bahasa Jepang, bahasa Mandari yang merupakan bahasabahasa popular untuk dipelajari (Kheng \& Baldauf, 2011, p. 952).

Sebagaimana diketahui penyebaran bahasa Inggris yang menjadikan bahasa Inggris sebagai bahasa asing di dunia dari lahir pada abad ke lima hingga sekarang yang akan dipaparkan sebagaimana berikut (Graddol, 2000, p. 7).

Periode Pra-bahasa Inggris ( Tahun 450)

Asal-usul bahasa Inggris dengan sangat baik didokumentasikan. Pada saat Romawi invasi abad 55 SM, adat bahasa Inggris adalah Celtic, dimana ada dua utama cabang yaitu Gaelic modern dan Welsh. Roma sendiri membuat bahasa Latin sebagai bahasa resmi dalam budaya dan pemerintah yang mengakibatkan banyak masyarakat di Inggris menjadi bilingual Celtic-Latin. Pasukan Garnisun kemudian tiba dari tempat lain di kekaisaran Romawi, khususnya Gaul, Celtic dan daerah lain. Di beberapa titik, bahasa Inggris telah berulang pada awal sejarah Latin yang dibawa ke banyak negara pada abad ke-19 sebagai bahasa dari kekuasaan kolonial dan membuat bahasa administrasi dimana diucapkan oleh sosial elit, akan tetapi tidak digunakan oleh mayoritas penduduk. Ini disajikan sebagai lingua franca internasional antara kalangan elit dari banyak negara. Tapi penggunaan Latin cepat menurun pada abad ke-17 dan ke-18.
Awal Bahasa Inggris Kuno (Tahun 450-850)

Bahasa Inggris dikembangkan setelah invasi Anglo-Saxon pada tahun 449, ketika Roma meninggalkan Inggris dan pemukim baru yang dibawa Dialek Jermanik dari daratan Eropa. Latin masih merupakan bahasa tertulis penting karena Gereja dan banyak kosakata Latin diperkenalkan ke dalam bahasa Inggris Kuno selama periode awal ini, akan tetapi bahasa mengembangkan bentuk baru yaitu bahasa Inggris lebih dulu muncul dalam bentuk teks-teks sastra.

Inggris Kuno Selanjutnya (Tahun 850-1100)

Masa ini adalah saat invasi dan penyelesaian dari Skandinavia dan waktu perubahan bahasa. Di utara Inggris dialek dari bahasa Inggris secara luas dipengaruhi oleh bahasa Skandinavia. Di selatan, Raja Alfred, prihatin jatuhnya standar pendidikan yang diatur karena banyak teks-teks Latin yang diterjemahkan ke dalam bahasa Inggris.

\section{Bahasa Inggris Pertengahan ( Tahun 1100-} 1450)

Penaklukan Norman pada tahun 1066 dan aturan-aturan yang membawa banyak perubahan linguistik. Bahasa Perancis pada periode ini sebagai bahasa resmi di Inggris, dimana mempengaruhi kosakata bahasa Ing-gris dan ejaan. Tata bahasa Inggris secara radikal juga berubah. Sedangkan Inggris Kuno menyatakan hubungan gramatikal melalui infleksi (akhiran kata), bahasa Inggris Pertengahan kehilangan banyak infleksi dan urutan-urutan kata yang digunakan untuk menandai Fungsi gramatikal kata benda. Orang-orang berpendidikan mungkin diperlukan untuk menyatukan tiga bahasa yaitu bahasa Prancis, Latin dan Inggris. Dalam hal ini merupakan periode perkembangan untuk sastra Inggris. Penulisnya diantaranya Geoffrey Chaucer dimana Bahasa yang mulai terlihat seperti bahasa Inggris modern.

Bahasa Inggris Modern Awal (Tahun 14501750)

Periode ini mencakup Renaissance, era Elizabethan dan Shakespeare. Ini adalah periode ketika negara-negara bangsa Eropa mengambil bentuk modern mereka. Peran Gereja dan Latin menurun. Di Inggris, lembagalembaga utama sains, seperti Royal Society, 
didirikan dan pada akhir abad ke-17, pencetus teori-teri seperti Isaac Newton sedang menulis penemuan mereka dalam bahasa Inggris dan bukan dari bahasa Latin. Bahasa Inggris tumbuh secara komersial dan memperoleh koloni luar negeri. Bahasa Inggris dibawa ke Amerika (koloni pertama di Jamestown, Virginia 1607) dan India (pos perdagangan pertama di Surat 1614). Dengan meningkatnya percetakan buku (buku pertama yang dicetak dalam bahasa Inggris 1473), bahasa Inggris mengakuisisi identitas tipografi yang stabil. Mengajar bahasa Inggris sebagai bahasa asing dimulai pada abad ke-16 dimana pertama kali dilaksanakan di Belanda dan Perancis.

\section{Bahasa Inggris Modern (Tahun 1750-1950)}

Bahasa Inggris telah menjadi bahasa nasional. Banyak upaya yang dibuat untuk standarisasi dan memperbaiki bahasa Inggris dengan kamus dan tata bahasa. Revolusi industri dipicu restrukturisasi kerja di dunia yang berhenti dan liburan yang membuat bahasa Inggris sebagai bahasa iklan internasional dan konsumerisme. Telegraf telah dipatenkan pada tahun 1837 yang menghubungkan masyarakat yang menggunakan bahasa Inggris sekitar dunia dan membangun bahasa Inggris sebagai bahasa utama untuk jasa kawat. Bahasa Inggris sebagai konsolidasi dari kekuasaan kekaisaran, pendidikan Inggris menengah diperkenalkan pada beberapa bagian dunia. Penggunaan bahasa Perancis diruang lingkup internasional menurun. Terbitan internasional pertama adalah Teks pengajaran bahasa Inggris diterbitkan dari Inggris pada tahun 1938 dan komersial TV pertama di dunia disiarkan di Amerika Serikat pada 1941. Inggris muncul sebagai bahasa kerja yang paling populer untuk lembaga transnasional.

\section{Bahasa Inggris Modern Terakhir (Tahun 1950- sekarang)}

Dengan mundurnya Inggris dari kekaisaran, varietas lokal dan sebagian standar bahasa Inggris telah muncul di baru merdeka negara. ELT telah menjadi industri sektor swasta besar. Setelah Perang Dunia II, Amerika Serikat menjadi ekonomi global dan Kehadiran budaya, membuat bahasa Inggris di Amerika mendominasi variasi dunia. Satelit komunikasi geostasioner yang pertama diluncurkan pada awal tahun 1965 dan Internet diciptakan oleh AS tahun 1970. Sebuah pasar dunia dalam produk audio visual diciptakan dan sinetron seperti Dallas beredar dunia. Di seluruh dunia, bahasa Inggris mulai digunakan pada saluran TV (seperti CNN International meluncurkan 1989). Sementara itu, Inggris telah memperoleh bentuk elektronik baru, sebagai fragmen interaksi tekstual dari reflektor Eropa utara untuk Internet Relay Chat.

Berdasarkan pemaparan diatas, bahasa Inggris kemudian digunakan sebagai bahasa Asing di era globalisasi. Diantaranya, bahasa Inggris banyak digunakan untuk bahasa penerbitan, pengumpulan informasi, konferensikonferensi, untuk penulisan yang tidak resmi dan korespodensi lisan, dan komunikasi tatap muka (Ammon, 2006, p. 2). Sebagaimana contohnya jurnal yang berjudul Angewandie Chemie dengan menggunakan bahasa Jerman berubah menjadi Applied Chemistry dengan menggunakan bahasa Inggris (Kheng \& Baldauf, 2011, p. 960). Penyebaran bahasa Inggris juga melalui penyebaran agama melalui tingginya kecepatan tehnologi informasi dalam masyarakat (Kheng \& Baldauf, 2011, p. 961). Contohnya di negara Australia, umat Kristen menyebarkan pesan agama melalui siaran langsung dalam TV nasional dan stasiun radio (Kheng \& Baldauf, 2011, p. 961).

Crystal, (2003) memberikan cacatan bahwa bahasa Inggris telah digunakan sebagai bahasa pers lebih dari 340 tahun sejak publikasi awal surat kabar British seperti London Gazette (1666) dan Lloyd's News (1696). Selain itu juga, jaringan Internasional seperti British Boadcasting Corporation (BBC), Columbia Broadcasting System (CBS), dan Cable News Network (CNN) yang masih mendominasi berita kabel melalui $\mathrm{TV}$, radio, dan Internet menggunakan bahasa Inggris (Kheng \& Baldauf, 2011, p. 962).

Bahasa Inggris banyak digunakan sebagai bahasa untuk mengiklankan produkproduk global ke Internasional. Sebagaimana contohnya, produk dari negara Jepang yang diekspor ke negara-negara lain meliputi merek Internasional seperti National, Sony, Thosiba menggunakan bahasa Inggris dalam instruksi produk-produknya (Kheng \& Baldauf, 2011, p. 962). Bahasa Inggris juga merupakan bahasa Internasional pertama di beberapa negara Asia dan sebagai faktor kunci dari kelangsungan hidup ekonomi untuk negara-negara dalam 
perubahan ekologi sosio-ekonomi (Mufwene, 2002).

Sementara itu, bahasa Jepang, ditopang oleh hegemoni ekonominya, tampaknya berkembang pesat terutama untuk komunikasi dalam perdagangan sedangkan bahasa Arab tampaknya berkembang pada negara-negara yang penduduknya banyak yang beragama Islam (Huda, 2011, p. 61). Sebagaimana contohnya Indonesia yang sebagian besar penduduknya beragama Islam, bahasa Arab digunakan sebagai bahasa dalam melaksanakan ibadah dalam agamanya. Sekolah-sekolah yang berbasis agama Islam baik sekolah negeri maupun swasta diajarkan bahasa Arab dari jenjang sekolah dasar, sekolah menengah pertama, sekolah menengah atas, dan perguruan tinggi (Huda, 2011, p. 68).

Bahasa Jerman merupakan bahasa yang penting untuk perdagangan (http://www.daadjkt.org/). Jerman adalah negara pengekspor utama di dunia. Jerman memiliki ekonomi yang kuat dan partner industri dan perdagangan paling penting bagi Indonesia di Uni Eropa. Penguasaan bahasa Jerman akan membantu masyarakat dalam membuka pasar baru dan menjadi sukses di bisnis global dan di pasar tenaga kerja internasional. Selain itu, bahasa Jerman menempati kedudukan kuat dalam pengetahuan dan sastra. Jerman sebagai salah satu bahasa pengetahuan dan teknologi memainkan peran penting dalam penelitian dan pendidikan. Di abad 19 bahasa Jerman sebagai bahasa pengetahuan dan sastra menduduki posisi penting di dunia.

Bahasa Mandarin yang sekarang diminati dan dipelajari oleh banyak orang karena kebangkitan ekonominya. Lajunya pertumbuhan perekonomian Cina sejak tahun 1990 hingga sekarang telah menjadikan Cina sebagai kekuatan perekonomian baru dunia. Geliat perekonomian Amerika Serikat dan negara-negara Eropa bahkan kini sudah kalah laju dibandingkan negara tirai bambu tersebut. Pertumbuhan ekonomi Cina rata-rata di atas 9 persen pertahun. Populasi warga keturunan Cina di seluruh dunia yang mencapai 1,9 miliar orang telah menyulap Bahasa Mandarin menjadi bahasa bisnis yang strategis di dunia internasional. Sehingga, bahasa Mandarin kini menjadi bahasa Internasional kedua setelah Bahasa Inggris (http://www.haluankepri.com).

\section{Pendidikan Bahasa Asing}

Kridalaksana (2011, p. 24) menyatakan bahwa bahasa asing adalah bahasa yang dikuasai oleh bahasawan, biasanya melalui pendidikan formal dan yang secara sosiokultural tidak dianggap bahasa sendiri. Definisi bahasa asing lainnya juga dapat dilihat dari tiga sudut yaitu wilayah asal, pemerolehan bahasa, dan fungsi sosio-kultural-politis (Huda, 2011, p. 62). Pertama, dari sudut asalnya dapat dirumuskan bahwa semua bahasa yang bukan berasal berasal dari wilayah Indonesia adalah bahasa Asing (Gunarwan, 1998). Kedua, dari sudut pemerolehan bahasa dapat dibedakan bahasa pertama (bahasa ibu), bahasa kedua (cenderung bahasa resmi/nasional), dan bahasa ketiga (bahasa asing) (Huda dan Croft dalam Huda, 2011, p. 63). Ketiga, dari sudut fungsi sosio-kultural-politis, bahasa asing adalah bahasa yang tidak digunakan dalam interaksi sosial sehari-hari, tidak dipakai untuk pengantar mata pelajaran di sekolah secara nasional, dan tidak dpakai sebagai alat komunikasi politik pemerintahan.

Bahasa asing yang dipelajari dan digunakan setiap orang di masing-masing negara itu berbeda-beda. Bahasa asing di dunia diantaranya meliputi bahasa Inggris, Perancis, Jerman, Arab, Jepang, Belanda, dll. Dalam fungsinya, pembelajaran bahasa asing memiliki beberapa conteks mengapa manusia membutuhkan belajar bahasa asing. Brown (2001, p. 116) menyatakan bahwa foreign language contexts are those in which students do not have ready-mode contexts for communication beyond in their classroom.

Berdasarkan pernyataan tersebut konteks pembelajaran bahasa asing berfungsi untuk tidak digunakan sebagai bahasa komunikasi di dalam kelas atau sekedar digunakan sebagai alat komunikasi dalam proses pendidikan di sekolah melainkan sebagai bahasa yang digunakan di luar kelas. Konteks pendidikan bahasa Asing di dalam kelas akan berfungsi untuk digunakan di luar kelas seperti klub bahasa, kepariwisatawan, media sosial, buku-buku dalam bahasa asing, film-film yang menggunakan percakapan dengan bahasa asing, acara TV atau radio, penulisan jurnal dalam bahasa asing seperti bahasa inggris untuk penulisan jurnal Internasional, dan lain sebagainya (Brown, 2001). 
National Standard in Foreign Language Education (Kusumah, 2007, p. 115) mengemukakan tujuan pendidikan bahasa asing adalah (1) memiliki kemahiran berkomunikasi dengan bangsa lain; (2) mengetahui dan memahami budaya yang terkandung dalam bahasa asing; (3) mengaitkan pengetahuan bahasa yang disiplin ilmu lain yang relevan; (4) membandingkan dan mengkontraskan bahasa yang dipelajarinya dengan bahasa lain; dan (5) merangkum keempat kemampuan tersebut, sehingga dia merasa nyaman menjadi warga dunia.

Di Indonesia diajarkan mata pelajaran bahasa Asing di sekolah dengan tujuan sebagaimana berikut Puskur Balitbang Depdiknas (Kusumah, 2007, p. 119). Pertama, mengembangkan kemampuan berkomunikasi dalam bahasa tersebut, dalam bentuk lisan dan tulisan yang meliputi kemampuan mendengarkan, berbicara, membaca, dan menulis. Kedua, menumbuhkan kesadaran tentang hakikat dan pentingnya bahasa Asing sebagai salah satu bahasa Asing untuk menjadi alat utama belajar. Dan ketiga, mengembangkan pemahaman tentang saling keterkaitan antar bahasa dan budaya serta memperluas cakrawala budaya.

\section{Kebijakan Pendidikan Bahasa Asing}

Kebijakan bahasa adalah sebuah isu dari pentingnya kritik yang terjadi di dunia pada saat ini (Spolsky, 2004). Kebijakan bahasa berjalan selama kurang lebih 50 tahun (Spolsky, 2004, p. ix). Dalam tujuannya dari sebuah teori kebijakan bahasa adalah untuk melaporkan dalam membuat pilihan dari pembicara berdasarkan susunan peraturan pemerintah yang dikenal oleh pembicara dari sebuah lingkup masyarakat (Spolsky, 2009, p. 1).

Perencanaan bahasa adalah sebuah bagian dari ide-ide, hukum-hukum dan kebijakan bahasa perubahan peraturan-peraturan, dan kebiasaan-kebiasaan yang diharapkan untuk mencapai sebuah perubahan perencanaan di dalam penggunaan bahasa di salah satu atau lebih lingkungan masyarakat (Nekvapil, 2011, p. 871). Dalam definisi tersebut, dinyatakan bahwa kebijakan bahasa merupakan sebuah bagian dari perencanaan bahasa.

Perencanaan bahasa dideskripsikan se-bagai pengesahan pemerintah, istilah panjang dan usaha sadar untuk merubah sebuah fungsi bahasa atau bentuk di dalam masyarakat yang bertujuan untuk menyelesaikan masalah bahasa (Kamwangalu, 2011, p. 888). Sebagaimana Spolsky (2004, p. 215) menyatakan bahwa perencanaan bahasa adalah tentang pilihan apa saja yang terdapat dalam sebuah hal spesifikasi bahasa, atau ekspresi, atau spesifikasi macam atau bahasa yang dihasilkan seorang individu, sebuah grup individu atau ahli.

Cooper, (1989) mendefinisikan perencanaan bahasa sebagai masalah yang harus diselesaikan atau kebiasaan yang harus berubah, bagaimana keputusan dijangkau dengan respek untuk mencapai tujuan-tujuan dan maksudmaksudnya, dan implementasi hasil, dan untuk setiap konteks social yang direncanakan itu dilekatkan. Rencana untuk mempelajari tentang perencanaan bahasa meliputi siapa pelakunya, percobaan terhadap pengaruh apa kelakuan-kelakuannya, orang-orangnya, untuk apa berakhir, dibawah kondisi apa, apa maksudnya, meliputi apa saja dalam proses membuat keputusan, dan apa saja efeknya (Cooper, 1989, pp. 97-98).

Language policies and social climates may diactate the status accorded to native and second language (Brown, 2001, p. 119). Berdasarkan pernyataan tersebut dapat kita simpulkan bahwa kebijakan sebuah bahasa itu dapat berfungsi sebagai bahasa pertama maupun bahasa kedua. Negara-negara di dunia banyak yang menggunakan bahasa Inggris sebagai bahasa Asing pertama (Spolsky, 2009, p. 107). Sebagaimana contohnya bahasa Inggris, seperti negara US dan Australia menggunakan bahasa Inggris sebagai bahasa kedua serta ada beberapa negara yang menjadikan bahasa Inggris sebagai bahasa Asing atau bahasa International seperti negara Jepang, Moroko, Thailand maupun Indonesia (Brown, 2001).

Wilayah-wilayah penyebaran kebijakan bahasa di mulai dari keluarga kemudian berpindah ke kelompok sosial, seperti gereja atau organisasi agama lain, tempat-tempat bekerja, sekolah dan sistem pendidikan yang lainnya, kelompok social dan olahraga, partai-partai politik, pemerintah daerah dan nasional, dan lain sebagainya (Spolsky, 2004, pp. 45-46). Dalam hal ini, sekolah merupakan sebuah wilayah dalam penerapan kebijakan bahasa. Oleh karena itu, setiap negara di dunia memiliki kebijakan pendidikan bahasa dalam pendidikan di sekolah-sekolah.

Pada tahun 2001, kebijakan Menteri Pendidikan Republik Rakyat China memerin- 
tahkan bahwa siswa-siswa di China harus belajar bahasa Inggris sebagai mata pelajaran wajib di kelas tiga (Spolsky, 2009, p. 108). Dalam keputusan ini memiliki lima alasan yaitu meningkatnya tuntutan bahasa Inggris di China, pentingnya pendidikan bahasa Inggris dalam perbaikan langsung dalam bidang teknologi, perluasan bahasa Inggris yang meningkat ke daerah- daerah sejak tahun 1978, fakta-fakta dari nilai yang dimulai sejak awal, dan dukungan dari wakil Perdana Meteri yang menulis sebuah buku setelah pension dari jabatannya yang berjudul pendidikan bahasa Asing. Hal ini menjadi sebuah masalah dengan cepatnya menjadi nyata, terutama kekurangan guru dan materi ajar (Hu dalam Spolsky, 2009, p. 108).

Pada umumnya, selanjutnya terdapat kecenderungan di negara-negara Eropa menjadikan bahasa Inggris sebagai mata pelajaran wajib sejak dini sebagai pembelajaran bahasa Asing seperti pada jenjang tingkat 5 di negara Perancis dan Netherland; jenjang tingkat 6 di negara Austria, Estonia, Sweden, Italia, Spain, Latvia, Croatia, Republik Czech, Polandia, dan Portugal; jenjang tingkat 7 di Inggris; dan jenjang tingkat 8 di Slovenia, Belgia, Yunani, dan German (Enever di Spolsky, 2009: 108).

Pemerintah Indonesia dalam GarisGaris Besar Haluan Negara (GBHN) 19992004 menempatkan bahasa Asing pada posisi yang sangat penting dalam konteks pendidikan nasional dan telah menyentuh berbagai wahana dalam kaitannya dengan politik, ekonomi, hukum, sosial dan budaya (Lengkanawati, 2007, p. 78). Selanjutnya, kebijakan pendidikan bahasa di Indonesia diatur dalam permendiknas Nomor 23 tahun 2006 (Menteri Pendidikan Nasional Republik Indonesia, 2006) tentang Standar Kompetensi Lulusan untuk Satuan Pendidikan Dasar dan Menengah, bahasa Inggris mulai diajarkan pada tingkat pendidikan sekolah menengah pertama. Serta kebijakan pendidikan bahasa Asing lainnya seperti bahasa Arab, bahasa Jerman, bahasa Perancis, bahasa Jepang, dan bahasa Mandarin diajarkan pada tingkat pendidikan Sekolah Menengah Atas sebagai mata pelajaran pilihan.

Puskur Balitbang Depdiknas (Kusumah, 2007, pp. 120-121) mengemukakan ruang lingkup mata pelajaran Bahasa Asing di Indonesia yang terdiri dari: (1) Keterampilan berbahasa yaitu menyimak, berbicara, membaca, dan menulis; (2) Sub-kompetensi yang meliputi kompetensi tindak bahasa, linguistic (kebahasaan), sosiokultural, strategi, dan kompetensi wacana serta (3) Pengembangan sikap yang positif terhadap bahasa Asing sebagai alat komunikasi.

\section{Implementasi Kebijakan Pendidikan Bahasa Asing di Indonesia}

Dalam menghadapi globalisasi, pemerintah salah satunya mengeluarkan kurikulum kebijakan pendidikan bahasa dalam kurikulum pendidikan nasional. Dalam perjalanan sejarah sejak tahun 1945, kurikulum pendidikan nasional telah mengalami perubahan sampai pada tahun 2015. Diantaranya, kebijakan bahasa Asing dalam kurikulum pendidikan nasional di Indonesia dari tahun 1950 sampai 1994 yang terdapat mulai pada jenjang sekolah Menengah Pertama sampai Sekolah Menengah Atas (Djojonegoro, 1996).

Kebijakan pendidikan bahasa Asing di Indonesia pada jenjang SMP adalah pendidikan bahasa Inggris yang mulai ada dicanangkan pada kurikulum tahun 1962 atau Rencana Pelajaran SMP Gaya Baru. Rencana Pelajaran SMP ini sesuai dengan Sistem Pendidikan Pancawardhana. Dalam kurikulum ini, kebijakan pendidikan bahasa Inggris masuk ke dalam mata pelajaran kelompok cipta. Kelompok cipta merupakan kelompok mata pelajaran yang bertujuan untuk memberikan dasar-dasar pengetahuan sehingga dapat mewujudkan tenaga kejuruan yang ahli (Djojonegoro, 1996, p. 127). Oleh karena itu, alokasi waktu mata pelajaran bahasa Inggris pada ditentukan berdasarkan tujuan Sistem Pendidikan Pancawardhana.

Kebijakan pendidikan bahasa Inggris pada jenjang SMP yang kedua pada kurikulum tahun 1968. Kurikulum ini merupakan perubahan dari kurikulum tahun 1962 yang disesuaikan dengan tuntutan Orde Baru. Dalam kurikulum ini, kebijakan pendidikan bahasa Inggris masuk ke dalam mata pelajaran kelompok Pembinaan Pengetahuan Dasar. Sehingga, alokasi waktu mata pelajaran bahasa Inggris pada ditentukan berdasarkan tuntutan Orde Baru.

Kebijakan pendidikan bahasa Inggris pada jenjang SMP yang ketiga pada kurikulum tahun 1975. Prinsip yang melandasi kurikulum SMP 1975 adalah fleksibilitas program, efisiensi, dan efektifitas, berorientasi pada tujuan, kontinuitas, dan pendidikan seumur hidup. Sistematika dalam penyususnan kurikulum ini 
meliputi tujuan institusional, struktur program, garis-garis besar pengajaran, sistem penyajian, dan sistem evaluasi SMP. Dalam kurikulum ini, kebijakan pendidikan bahasa Inggris masuk ke dalam mata pelajaran program pendidikan akademis. Oleh karena itu, alokasi waktu mata pelajaran bahasa Inggris pada ditentukan berdasarkan tujuan program akademis pada kurikulum ini.

Kebijakan pendidikan bahasa Inggris pada jenjang SMP yang keempat pada kurikulum tahun 1984. Tujuan pendidikan SMP pada kurikulum 1984 adalah untuk mendidik siswa menjadi manusia pembangunan dan warga negara Indonesia yang berpedoman pada Pancasila dan UUD 1945; memberikan bekal kemampuan yang diperlukan siswa untuk dapat melanjutkan pendidikannya ke lembaga pendidikan yang lebih tinggi, dan memberikan bekal keterampilan dasar untuk memasuki kehidupan di masyarakat sesuai dengan minat, kemampuan, dan lingkungannya. Dalam kurikulum ini, kebijakan pendidikan bahasa Inggris masuk ke dalam mata pelajaran program pendidikan akademis. Oleh karena itu, alokasi waktu mata pelajaran bahasa Inggris pada ditentukan berdasarkan tujuan program akademis pada kurikulum ini.

Kebijakan pendidikan bahasa Inggris pada jenjang SMP yang kelima pada kurikulum tahun 1994. Tujuan pendidikan SMP pada kurikulum 1994 adalah untuk memberikan bekal kemampuan dasar yang merupakan perluasan serta peningkatan pengetahuan dan keterampilan yang diperoleh di sekolah dasar yang bermanfaat bagi siswa untuk mengembangkan kehidupannya sebagai pribadi, anggota masyarakat, dan warga negara sesuai dengan tingkat perkembangannya serta mempersiapkan mereka untuk mengikuti pendidikan menengah. Dalam kurikulum ini, alokasi waktu mata pelajaran bahasa Inggris pada ditentukan berdasarkan tujuan pendidikan kurikulum ini.

Kebijakan pendidikan bahasa Inggris pada jenjang SMP yang keenam pada kurikulum tahun 2004. Kurikulum 2004 merupakan kurikulum yang berorientasi pada kompetensi atau disebut dengan Kurikulum Berbasis Kompetensi (KBK). Dalam kurikulum ini, kebijakan pendidikan bahasa Inggris masuk ke dalam mata pelajaran wajib. Dalam kurikulum ini, alokasi waktu mata pelajaran bahasa
Inggris pada ditentukan berdasarkan tujuan pendidikan kurikulum ini.

Kebijakan pendidikan bahasa Inggris pada jenjang SMP yang ketujuh pada kurikulum tahun 2006. Kurikulum ini merupakan penyempurnaan dari kurikulum 2004 dan disebut dengan KTSP (Kurikulum Tingkat Satuan Pelajaran) karena kurikulum yang bertujuan pada tingkat satuan pelajaran. Dalam kurikulum ini, kebijakan pendidikan bahasa Inggris masuk ke dalam mata pelajaran wajib. Dalam kurikulum ini, alokasi waktu mata pelajaran bahasa Inggris pada ditentukan berdasarkan tujuan pendidikan kurikulum ini.

Kebijakan pendidikan bahasa Inggris pada jenjang SMP yang terakhir pada kurikulum tahun 2013. Tujuan pengembangan Kurikulum 2013 terutama adalah untuk mengatasi masalah dan tantangan berupa kompetensi riil yang dibutuhkan oleh dunia kerja, globalisasi ekonomi pasar bebas, membangun kualitas manusia Indonesia yang berakhlak mulia, dan menjadi warga negara yang bertanggung jawab. Pada hakikatnya pengembangan Kurikulum 2013 adalah upaya yang dilakukan melalui salah satu elemen pendidikan, yaitu kurikulum untuk memperbaiki kualitas hidup dan kondisi sosial bangsa Indonesia secara lebih luas. Jadi, pengembangan kurikulum 2013 tidak hanya berkaitan dengan persoalan kualitas pendidikan saja, melainkan kualitas kehidupan bangsa Indonesia secara umum. Dalam kurikulum ini, kebijakan pendidikan bahasa Inggris masuk ke dalam mata pelajaran wajib. Dalam kurikulum ini, alokasi waktu mata pelajaran bahasa Inggris pada ditentukan berdasarkan tujuan pendidikan kurikulum ini.

Kebijakan pendidikan bahasa Asing di Indonesia pada jenjang SMA adalah pendidikan bahasa Asing yang mulai ada dicanangkan pada kurikulum tahun 1952. Kurikulum ini ini dikembangkan karena kurikulum 1950/1951 bersifat terlalu akademik dan kurang memperhatikan keterampilan dan moral siswa sehingga kurikulum ini tidak sesuai dengan tujuan SMA yang mempersiapkan murid masuk ke perguruan tinggi dan ke masyarakat. Kebijakan bahasa Asing dalam kurikulum ini adalah mata peljaran bahasa Inggris, bahasa Perancis, dan bahasa Jerman. Dalam kurikulum ini, kebijakan pendidikan bahasa Asing masuk ke dalam mata pelajaran golongan pokok. Kebijakan pendidikan bahasa Asing termasuk alokasi waktu mata pelajaran bahasa 
Inggris pada dikembangkan karena kurikulum 1950/1951bersifat terlalu akademik dan kurang memperhatikan keterampilan dan moral siswa sehingga kurikulum ini tidak sesuai dengan tujuan SMA.

Kebijakan pendidikan bahasa Inggris yang kedua pada jenjang SMA pada kurikulum tahun 1968. Kurikulum SMA 1968 bertujuan untuk mengembalikan posisi pendidikan nasional yang berdasarkan Pancasila setelah terjadi peristiwa G-30 S/PKI pada tahun 1950. Oleh karena itu, alokasi waktu pada kurikulum ini ditentukan berdasarkan tujuan mengembalikan posisi pendidikan nasional yang berdasarkan Pancasila.

Kebijakan pendidikan bahasa Inggris pada jenjang SMA yang ketiga pada kurikulum tahun 1975.Tujuan pendidikan SMA pada kurikulum ini untuk meningkatkan proses belajar-mengajar untuk menghasilkan lulusan sebagai warga negara yang baik, sebagai manusi yang utuh, sehat, kuat lahir dan batin; menguasai hasil pendidikan umum yang merupakan kelanjutan dari pendidikan SMA; memiliki bekal untuk melanjutkan studinya ke lembaga pendidikan yang lebih tinggi; dan memiliki bekal untuk terjun ke masyarakat. Dalam kurikulum ini, kebijakan pendidikan bahasa Inggris masuk ke dalam mata pelajaran program pendidikan akademis. Oleh karena itu, alokasi waktu mata pelajaran bahasa Inggris pada ditentukan berdasarkan tujuan program akademis pada kurikulum ini.

Kebijakan pendidikan bahasa Inggris pada jenjang SMA yang keempat pada kurikulum tahun 1984. Tujuan pendidikan SMA pada kurikulum 1984 adalah untuk mendidik siswa menjadi manusia pembangunan dan warga negara Indonesia yang berpedoman pada Pancasila dan UUD 1945; memberikan bekal kemampuan yang diperlukan siswa untuk dapat melanjutkan pendidikan di perguruan tinggi terutama di universitas dan institusi, dan memberikan bekal kemampuan yang diperlukan bagi siswa yang akan melanjutkan pendidikan di sekolah tinggi, akademisi, politeknik, program lainnya, dan memberi bekal kemampuan bagi siswa yang akan terjun ke dunia kerja setelah menyelesaikan pendidikannya. Dalam kurikulum ini, kebijakan pendidikan bahasa Inggris masuk ke dalam mata pelajaran program pendidikan inti untuk kelas $\mathrm{X}$ dan program pendidikan pilihan untuk kelas XI dan XII. Oleh karena itu, alokasi waktu mata pel- ajaran bahasa Inggris pada ditentukan berdasarkan tujuan program pada kurikulum ini baik program inti maupun program pilihan.

Kebijakan pendidikan bahasa Inggris pada jenjang SMA yang kelima pada kurikulum tahun 1994. Penyebutan SMU (Sekolah Menengah Umum) dilaksanakan mulai tahun 1994 sejak berlakunya kurikulum 1994 sebagai pengganti SMA. Tujuan pendidikan SMU pada kurikulum 1994 adalah menyiapkan siswa untuk melanjutkan pendidikan pada jenjang pendidikan tinggi. Dalam kurikulum ini, alokasi waktu mata pelajaran bahasa Inggris pada ditentukan berdasarkan tujuan pendidikan kurikulum ini.

Kebijakan pendidikan bahasa Inggris pada jenjang SMA yang keenam pada kurikulum tahun 2004. Kurikulum 2004 merupakan kurikulum yang berorientasi pada kompetensi atau disebut dengan Kurikulum Berbasis Kompetensi (KBK). Dalam kurikulum ini, kebijakan pendidikan bahasa Inggris masuk ke dalam mata pelajaran wajib. Dalam kurikulum ini, alokasi waktu mata pelajaran bahasa Inggris pada ditentukan berdasarkan tujuan pendidikan kurikulum ini.

Kebijakan pendidikan bahasa Inggris pada jenjang SMA yang ketujuh pada kurikulum tahun 2006. Kurikulum ini merupakan penyempurnaan dari kurikulum 2004 dan disebut dengan KTSP (Kurikulum Tingkat Satuan Pelajaran) karena kurikulum yang bertujuan pada tingkat satuan pelajaran. Dalam kurikulum ini, kebijakan pendidikan bahasa Inggris masuk ke dalam mata pelajaran wajib. Dalam kurikulum ini, alokasi waktu mata pelajaran bahasa Inggris pada ditentukan berdasarkan tujuan pendidikan kurikulum ini.

Kebijakan pendidikan bahasa Inggris pada jenjang SMA yang terakhir pada kurikulum tahun 2013. Tujuan pengembangan Kurikulum 2013 terutama adalah untuk mengatasi masalah dan tantangan berupa kompetensi riil yang dibutuhkan oleh dunia kerja, globalisasi ekonomi pasar bebas, membangun kualitas manusia Indonesia yang berakhlak mulia, dan menjadi warga negara yang bertanggung jawab. Pada hakikatnya pengembangan Kurikulum 2013 adalah upaya yang dilakukan melalui salah satu elemen pendidikan, yaitu kurikulum untuk memperbaiki kualitas hidup dan kondisi sosial bangsa Indonesia secara lebih luas. Jadi, pengembangan kurikulum 2013 tidak hanya berkaitan dengan persoalan kualitas pendidik- 
an saja, melainkan kualitas kehidupan bangsa Indonesia secara umum. Dalam kurikulum ini, kebijakan pendidikan bahasa Inggris masuk ke dalam mata pelajaran wajib serta kebijakan pendidikan Bahasa Asing lainnya (Korea, Jepang, Jerman, Perancis, Arab) sebagai mata pelajaran pilihan. Dalam kurikulum ini, alokasi waktu mata pelajaran bahasa Inggris pada ditentukan berdasarkan tujuan pendidikan kurikulum ini.

Berdasarkan pemaparan kebijakan pendidikan Bahasa Asing seperti bahasa Korea, Jepang, Jerman, Perancis, dan Arab di Indonesia mengalami perubahan dari masa setelah kemerdekaan hingga saat ini. Perubahan ini disebabkan karena perubahan kurikulum yang mengalami karena penyempurnaan kurikulum-kurikulum sebelumnya. Sehingga, kebijakan pendidikan Bahasa Asing disesuaikan dengan tujuan kurikulum-kurikulum dari masa setelah kemerdekaan hingga saat ini.

Berdasarkan Undang-Undang Republik Indonesia Nomor 20 tahun 2003 (Depdiknas, 2003), Depdiknas menjadikan Ujian Nasional biasa disingkat UN/UNAS sebagai sistem evaluasi standar pendidikan dasar dan menengah secara nasional dan persamaan mutu tingkat pendidikan antar daerah yang dilakukan oleh Pusat Penilaian Pendidikan. Dalam kebijakan pemerintah menjadikan bahasa Inggris sebagai salah salah mata pelajaran yang diujikan dalam UN (Ujian Nasional) yang dimulai jenjang SMP, SMA dan SMK.

Pemerintah Indonesia dalam menghadapi globalisasi juga mengeluarkan kebijakan mendirikan Rintisan Sekolah Bertaraf Internasional atau disingkat RSBI sejak tahun 2005. RSBI adalah suatu program pendidikan yang ditetapkan oleh Menteri Pendidikan Nasional berdasarkan Undang-Undang No. 20 tahun 2003 pasal 50 ayat 3 , yang menyatakan bahwa Pemerintah dan/atau Pemerintah Daerah menyelenggarakan sekurang-kurangnya satu pendidikan pada semua jenjang pendidikan untuk dikembangkan menjadi satuan pendidikan yang bertaraf internasional. Di sekolah-sekolah bertaraf RSBI, penggunaan bahasa Inggris sebagai bahasa pengantar dalam tiap mata pelajaran dalam sekolah.

Akan tetapi, Mahkamah Konstitusi (MK) membubarkan Rintisan Sekolah Bertaraf Internasional (RSBI) pada sekolah-sekolah pemerintah (www.tribunnews.com/nasional/ 2013/01/08). Pembubaran itu disampaikan MK dalam sidang putusan pembatalan Pasal 50 ayat 3 Undang-undang Nomor 20 Tahun 2003 tentang Sistem Pendidikan Nasional (Sisdiknas) di Gedung Mahkamah Konstitusi di Jakarta. Dalam keputusannya, Mahkamah Konstitusi menyatakan pasal yang mengatur RSBI/ SBI yang berada di sekolah-sekolah pemerintah bertentangan dengan UUD 1945 dan tidak mempunyai kekuatan hukum terikat.

Pembubaran tersebut juga berdasarkan pendapat Mahkamah Konstitusi bahwa sekolah bertaraf internasional di sekolah pemerintah itu bertentangan dengan UUD 1945, RSBI yang menimbulkan dualisme pendidikan, kemahalan biaya menimbulkan adanya diskriminasi pendidikan RSBI, pembedaan antara RSBI/ SBI dengan non RSBI/SBI menimbulkan adanya kastanisasi pendidikan. Pertimbangan selanjutnya yaitu mengenai penggunaan bahasa Inggris sebagai bahasa pengantar dalam tiap mata pelajaran dalam sekolah RSBI/SBI dinilai dapat mengikis jati diri bangsa, melunturkan kebanggaan generasi muda terhadap penggunaan dan pelestarian bahasa Indonesia sebagai alat pemersatu bangsa. Seperti yang diberitakan, pasal RSBI/SBI ini digugat oleh sejumlah orang tua murid, dosen, dan aktivis pendidikan seperti ICW. Mereka menilai RSBI/SBI rentan penyelewengan dana, menimbulkan diskriminasi dan kastanisasi pendidikan, serta mahalnya biaya pendidikan.

Kebijakan pendidikan bahasa Asing di Indonesia lainnya adalah pada tahun 2015 mengeluarkan kebijakan pendidikan bahasa Asing dalam menyambut Masyarakat Ekonomi Asia (MEA). Dalam menyambut pasar global dan bebas dengan bingkai Masyarakat Ekonomi ASEAN (MEA) yang akan mulai bergulir pada Desember 2015, maka Indonesia sebagai salah satu negara tergabung dalam MEA tersebut harus siap menghadapi globalisasi yang dimaksud. Pasalnya, pemberlakuan MEA 2015 ini menyebabkan lalu lintas perdagangan bebas di kawasan Asia Tenggara menjadi tanpa kendala. Perdagangan bebas dapat diartikan tidak ada hambatan tariff maupun hambatan nontarif bagi negara-negara anggota ASEAN.

Kondisi ini tentunya menjadi tantangan sendiri bagi Indonesia dari segala bidang, baik aspek ekonomi, politik, pendidikan dan budaya. Karena dalam menghadapi MEA 2015, Indonesia masih memiliki berbagai pekerjaan rumah yang harus ditingkatkan agar tetap memiliki daya saing. 
Untuk pilar sosial budaya, Indonesia masih perlu kerja keras mengingat masih banyak warga Indonesia yang belum mengetahui tentang ASEAN. Padahal salah satu kunci keberhasilan MEA adalah konektivitas atau kontak antara satu warga negara dengan negara ASEAN lainnya. Sedangkan salah satu media yang paling ampuh untuk membangun konektivitas dengan negara-negara ASEAN adalah melalui bahasa asing, yaitu diantaranya Bahasa Inggris.

Bahasa Inggris dari hasil survei oleh Lewis (2009) yang menunjukkan bahwa Bahasa Inggris menempatkan peringkat ke-3 sebagai bahasa yang paling banyak digunakan di negara-negara di dunia dari total 172 bahasa yang tercatat (Hamidia, 2015). Bahasa Inggris diketahui telah digunakan oleh kurang lebih 112 negara di dunia termasuk di dalamnya negara-negara kawasan ASEAN dan 328 juta pengguna bahasa. Dari hasil survei tersebut dapat disimpulkan bahwa bahasa Inggris adalah bahasa yang paling banyak digunakan oleh negara-negara di dunia. Meskipun jumlah pengguna bahasa Inggris lebih sedikit dari jumlah pengguna bahasa Spanyol dan Mandarin yang menduduki peringkat pertama dan kedua, namun bahasa Inggris mempunyai jumlah negara pengguna bahasa paling banyak dari 172 bahasa dunia.

Dari paparan tersebut, masyarakat Indonesia harus mampu menggunakan bahasa Inggris untuk menghadapi MEA 2015. Menguasai bahasa Inggris bukan berarti melupakan atau mendiskriminasikan bahasa Indonesia, namun dalam hal ini kita harus menjadikan bahasa Inggris sebagai media untuk mengenalkan bahasa Indonesia kepada negara-negara ASEAN. Inilah peran bahasa Inggris yang sesungguhnya untuk kemajuan Indonesia.

Untuk menghadapi MEA, Kementerian Pendidikan dan Kebudayaan (Kemendikbud) menginstruksikan bahwa mulai tahun ajaran baru 2015/2016 untuk seluruh sekolah menerapkan tiga bahasa yakni bahasa Indonesia, Inggris dan daerah (Hadi, 2015). Instruksi itu dilayangkan ke seluruh sekolah di Indonesia guna mempersiapkan pelajar menyambut Masyarakat Ekonomi Asean (MEA) pada Desember 2015 mendatang. Tahirin (dalam http://www.infopgri.tk/2015/07/) mengatakan bahwa berita paling terbaru tentang bahasa daerah akan dimasukkan ke dalam kurikulum sekolah. Dengan adanya instruksi ini mempercepat dalam memasukkan bahasa daerah ke dalam kurikulum melalui pembelajaran muatan lokal. Sedangkan bahasa Indonesia sudah lama menjadi pelajaran wajib, begitu juga pelajaran bahasa Inggris. Selain itu, Tahirin (dalam http://www.infopgri.tk/2015/07/) juga menegaskan pernyataannya bahwa bahasa Indonesia berfungsi sebagai bahasa resmi kenegaraan, pengantar pendidikan, komunikasi tingkat nasional, pengembangan kebudayaan nasional, transaksi dan dokumentasi niaga, serta sarana pengembangan dan pemanfaatan ilmu pengetahuan, teknologi, seni dan bahasa media massa.

Berdasarkan pemaparan tersebut, pemerintah wajib mengembangkan, membina dan melindungi bahasa dan sastra Indonesia agar tetap memenuhi kedudukan dan fungsinya dalam kehidupan bermasyarakat, berbangsa dan bernegara sesuai dengan perkembangan zaman. Selain itu, pemerintah daerah juga wajib melindungi bahasa dan sastra agar tetap menjadi bagian dari kekayaan budaya Indonesia. Termasuk bahasa dan budaya masing daerah. Sehingga, dalam perjalanannya nanti, bahasa inggris, bahasa Indonesia dan bahasa daerah juga akan tetap akan diperhatikan sama besarnya. Ketiga bahasa tersebut menunjang MEA yang akan dihadapi oleh peserta didik termasuk seluruh siswa di Indonesia.

Dengan adanya instruksi tersebut, peserta didik sebagai manusia terdidik harus mampu menyiapkan kemampuannya dalam hal wawasan kebudayaan lokal dan mengasah kemampuan bahasa Inggrisnya. Sehingga dengan demikian akan sangat mudah bagi kaum akademisi untuk mengembangkan potensi wisata dan kebudayaan lokal khususnya kepada wisatawan asing. Namun, penguasaan Bahasa Inggris disini tidak hanya terbatas pada sektor wisata, artinya para pelajar atau mahasiswa Indonesia tidak hanya bisa menjadi pemandu wisata, melalui bahasa Inggris, kita juga bisa menguasai segala bidang, seperti mengembangkan ekonomi kreatif dan mengenalkan bahasa Indonesia.

\section{SIMPULAN}

Dalam menghadapi era globalisasi yang ditandai oleh kemajuan yang pesat dalam teknologi informasi dan komunikasi telah menjadikan penguasaan bahasa asing (Inggris, Perancis, Mandarin, Jepang, Jerman, dan baha- 
sa asing lainnya) sebagai syarat utama untuk mengembangkan diri sehingga mampu bersaing di tengah masyarakat global. Penguasaan bahasa asing merupakan persyaratan penting bagi keberhasilan individu dalam menjawab tantangan zaman. Pendidikan bahasa Asing dapat dijadikan salah satu sarana utama dalam rangka meningkatkan kualitas diri, masyarakat, dan bangsa. Bahasa yang dimiliki oleh bangsa akan unggul dalam bidang ekonomi, politik, dan iptek memiliki peluang menjadi wahana komunikasi global.

Dalam menghadapi era globalisasi tersebut, negara-negara di dunia memiliki kebijakan bahasa Asing di negaranya masingmasing. Sebagaimana diketahui Indonesia mengeluarkan kebijakan pendidikan bahasa Asing pada kurikulum pendidikan nasional dari Indonesia merdeka sampai saat ini. Kebijakan pendidikan bahasa Asing di Indonesia telah mengalami perubahan dari Indonesia merdeka sampai saat ini guna untuk menyikapi perubahan era globalisasi yang terjadi di dunia. Untuk menyikapi era globalisasi, pemerintah Indonesia perlu memasukkan pendidikan bahasa daerah sebagai mata pelajaran wajib dalam kurikulum pendidikan nasional supaya bahasa daerah tidak hilang dalam pergeseran era globalisasi. Selain itu, pemerintah Indonesia harus menjadikan bahasa Indonesia selain menjadi bahasa nasional juga menjadi bahasa Asing di lingkup dunia.

\section{DAFTAR PUSTAKA}

Ammon, U. (2006). Language planning for international scientific communication: An overview of questions and potential solutions. Current Issues in Language Planning, 7(1), 1-30. https://doi.org/10.2167/cilp088.0

Brown, H. D. (2001). Teaching by principles: An interactive approach to language pedagogy (2nd ed.). New York: Pearson Education.

Cooper, R. L. (1989). Language planning and social change. Cambridge: CUP.

Crystal, D. (2003). English as a global language (2nd ed.). Cambridge: Cambridge University Press.

Depdiknas. Undang-Undang Nomor 20 Tahun 2003 tentang Sistem Pendidikan
Nasional (2003). Jakarta.

Djojonegoro, W. (1996). Lima puluh tahun perkembangan pendidikan Indonesia. Jakarta: Departemen Pendidikan dan Kebudayaan Badan Penelitian dan Pengembangan Pendidikan dan Kebudayaan.

Graddol, D. (2000). The future of English? London: The English Company (UK) Ltd.

Gunarwan, A. (1998). Kedudukan dan fungsi bahasa asing di Indonesia di dalam era global. In Kongres Bahasa Indonesia VII. Jakarta.

Hadi, W. (2015). Ini dia kebijakan baru Kemendikbud di tahun ajaran baru 2015/2016!! Retrieved December 9, 2015, from http://www.infopgri.tk/2015/07/ini-diakebijakan-baru-kemendikbud-di.html

Hamidia, M. (2015). Peran bahasa Inggris menghadapi MEA. Retrieved December 9, 2015, from http://www.medanbisnisdaily.com/news/ $\mathrm{read} / 2015 / 09 / 23 / 188242 /$ peran-bahasainggris-menghadapimea/\#.VmeOHF7xnMwv

Huda, N. (2011). Kedudukan dan fungsi bahasa asing. In H. Alwi \& D. Sugono (Eds.), Plotik Bahasa; Rumusan Seminar Politik Bahasa. Jakarta: Jakarta: Badan Pengembangan dan Pembinaan Bahasa Kementrian Pendidikan dan Kebudayaan.

Jarvis, P. (2007). Globalization, lifelong learning and the learning society: sociological perspectives. London: Routledge.

Kamwangalu, N. (2011). Language planning: Approaches and methods. In E. Hinkel (Ed.), Handbook of research in secondlanguage teaching and learning Volume II. New York \& London: Routldge.

Kheng, C. C. S., \& Baldauf, R. B. (2011). Language planning: approaches and methods. In E. Hinkel (Ed.), Handbook of research in second-language teaching and learning - Volume II. New York \& 
London: Routldge.

Kridalaksana, H. (2011). Kamus linguistik. Jakarta: Gramedia Pustaka Utama.

Kusumah, I. Y. (2007). Pendidikan bahasa asing. Dalam ilmu dan aplikasi Pendidikan bagian III: Pendidikan disiplin ilmu. (tim pengembangan ilmu pendidikan). Bandung: PT Imperial Bhakti Utama.

Lengkanawati, N. S. (2007). Pendidikan bahasa. In Tim Pengembangan llmu Pendidikan (Ed.), Ilmu dan Aplikasi Pendidikan bagian III: Pendidikan Disiplin Ilmu. Bandung: PT Imperial Bhakti Utama.

Lewis, P. (2009). Ethnologue: languages of the world (16th ed.). Texas: SIL International.

Menteri Pendidikan Nasional Republik Indonesia. Peraturan Menteri Pendidikan Nasional Nomor 23 tahun 2006 tentang standar kompetensi lulusan untuk satuan pendidikan dasar dan menengah (2006).

Mufwene, S. S. (2002). Colonisation, globalisation, and the future of languages in the twenty-first century. MOST Jurnal on Multicultural Societies, 4(2).

Nekvapil, J. (2011). The history and theory of language planning. In E. Hinkel (Ed.), Handbook of research in secondlanguage teaching and learning Volume II. New York \& London: Routldge.

Spolsky, B. (2004). Language policy. New York: Cambridge University Press.

Spolsky, B. (2009). Language management. New York: Cambridge University Press.

Steger, M. (2003). Globalization: A very short introduction. New York: Oxford University Press. 